\title{
Effect of (+)-cyanidanol-3 on chronic active hepatitis: a double blind controlled trial
}

\author{
S BAR-MEIR, Z HALPERN, M GUTMAN, Z SHPIRER, MIMI BARATZ, \\ AND D BASS \\ From the Departments of Gastroenterology and Pathology, Ichilov Hospital, Tel Aviv and Department \\ of Gastroenterology, Kaplan Hospital, Rehovot, Israel
}

SUMMARY Forty patients with biopsy proven chronic active hepatitis were studied, 22 received (+)-cyanidanol-3 in a dose of $3 \mathrm{~g}$ daily and 18 placebo. Side effects related to cyanidanol were fever (four patients), haemolysis (one patient) and urticaria (one patient). All side effects subsided on discontinuation of the medication. Cyanidanol had an effect no better than placebo on symptoms, laboratory tests, and histological findings on liver biopsy.

(+)-cyanidanol-3, a flavonoid substance has been shown to decrease the hepatotoxicity of ethanol, ${ }^{1}$ galactosamine ${ }^{2}$ and other compounds in laboratory animals. It is a free radical scavenger ${ }^{3}$ which inhibits lipid peroxidation by hepatotoxic chemicals ${ }^{45}$ and thus protects the liver of experimental animals from various heptotoxic substances. ${ }^{146}$

Patients with acute viral hepatitis treated with cyanidanol showed in some studies, a faster decline of bilirubin and aminotransferases. ${ }^{7-13}$ Patients with chronic active hepatitis treated with cyanidanol did not show significant differences from a placebo treated group in the evaluation of symptoms, results of laboratory tests or the histological findings. ${ }^{14}$ Another trial showed that in association with corticosteroids, cyanidanol is more effective against the histological lesions of chronic active hepatitis than is placebo combined with the same corticoid. ${ }^{15}$ The histological improvement was more pronounced in the HBsAg-negative patients. It had no effect on clinical and biological evaluation.

The present study was designed to evaluate in a double blind placebo controlled trial the effect of cyanidanol on chronic active hepatitis with special emphasis on histology.

\section{Methods}

\section{PATIENTS}

A prospective, double blind, placebo controlled trial of cyanidanol was carried out in 40 patients with

Address for correspondence: S Bar-Meir, MD, Department of Gastroenterology, The Edith Wolfson Hospital, PO Box 5, Holon 58100, Israel.

Received for publication 1 November 1984 biopsy proven chronic active hepatitis. All had the disease for at least six months with either serum asparate aminotransferase (AST) lesser than 10 times the upper limit of normal or five times the upper limit of normal with a two-fold increase in $\gamma$-globulin concentrations. Patients with alcohol consumption of more than $15 \mathrm{~g} /$ day were excluded.

Cyanidanol was given in a dose of $3 \mathrm{~g}$ daily for six months and placebo in a dose of two tablets three times daily. Patients were seen at two and one weeks before randomisation, on the day of randomisation, one week later, and at a monthly interval for the next six months. On each visit symptoms were noted, a complete physical examination was made and a number of laboratory tests were undertaken. The following symptoms were noted: asthenia, nausea, anorexia, pruritus, and abdominal pain. The physical examination was mainly concerned with the following signs: icterus, liver tenderness, hepatomegaly, splenomegaly, and ascites. The following blood tests were made at each visit: red blood cell, reticulocyte and white blood cell counts including differential, glucose, BUN, electrolytes, cholesterol, uric acid, haptoglobin, alanine aminotransferase (ALT), AST, bilirubin, alkaline phosphatase, prothrombin time, total protein, albumin, and globulin. Determination of serum immunoglobulins and $\mathrm{HBsAg}$ were determined in each patient at least once at the beginning of the study. Additional determinations of $\mathrm{HBsAg}$ were carried out during the six month period in each of the patients who were positive for $\mathrm{HBsAg}$.

Liver biopsies were done within two weeks before the initiation of the study and the end of the study. 
All biopsies were evaluated blindly by the two of us (MB, SB). The histological features were assessed according to the following criteria: presence and severity of piecemeal necrosis, intralobular necrosis, portal inflammation, portal fibrosis, intralobular fibrosis, steatosis, cholestasis, and eventual development of cirrhosis. Each parameter was again scaled $0-3$. For each patient, histological features of the disease at the beginning and the end of the follow up period were compared and classified as improved, no change or worsened.

Improvement was defined as a decrease in the amount of necrosis and inflammation in the periportal and portal area without a concomitant increase in the amount of fibrosis. A biopsy was considered worse when either the amount of necrosis and inflammation in the periportal and portal area increased or fibrosis became more pronounced. Obviously the conversion from a non-cirrhotic to a cirrhotic liver was considered as a deterioration.

A change in a biochemical parameter was considered as significant when it was more or less than $50 \%$ of the initial value.

\section{Results}

Twenty two patients received cyanidanol and 18 placebo. Ten patients were excluded, six from the cyanidanol group because of fever, haemolysis or urticaria and four from the placebo group because of death, pregnancy, or misdiagnosis (Table 1). All patients who were excluded because of fever or urticaria had the same reaction when rechallenged. The haemaloysis was a severe Coombs positive haemolytic anemia which improved when the medication was discontinued. The death was related in both patients to upper gastrointestinal bleeding with hepatic encephalopathy. One patient was excluded because the liver biopsy was interpreted later as primary biliary cirrhosis rather than chronic active hepatitis.

Thirty patients, 16 on cyanidanol and 14 on placebo, continued therapy for six months. The second liver biopsy at the end of the study was refused by six patients, three of each group.

Both groups were similar as regard to age, sex, symptoms, and physical findings (Table 2). None of the patients was jaundiced and only one per cent in
Table 1 Causes for exclusion from the study

\begin{tabular}{lcc}
\hline & \multicolumn{2}{c}{$\begin{array}{c}\text { Cyanindanol } \\
\text { Patients }\end{array}$} \\
\hline no)
\end{tabular}

the placebo group had slightly raised serum bilirubin, $25 \mu \mathrm{mol} / 1$. There were two patients in the placebo group and none in the cyanidanol group who were $\mathrm{HBsAg}$ positive. The liver function tests were similar in both groups except for serum AST which was slightly higher in the placebo group ('Table 3). The initial liver histology was also similar in both groups (Table 4). Cirrhosis was seen on the initial liver biopsy in eight of the patients on cyanidanol and in nine of the patients on placebo. None had cholestasis.

The symptoms and the physical findings did not change significantly during the study (Table 5); variations in the laboratory tests at the end of six months were similar in both groups (Table 6). The similarity between the two groups stayed the same when only $25 \%$ variation was considered significant change.

During the six months the liver biopsy became worse significantly more often in patients who were on cyanidanol than in patients who were on placebo $(p=0.02)($ Table 7). One of the patients who was on cyanidanol and two of the patients who were on placebo developed cirrhosis during the period of the study.

The two HBsAg positive patients received placebo. One patient stayed unchanged based on clinical, biochemical, and histological criteria. The other patient became worse during the six month period.

\section{Discussion}

In this study, cyanidanol therapy, $3 \mathrm{~g}$ per day for six months, did not have any effect on patient with chronic active hepatitis. The criteria for inclusion in the study were such that only patients with mild or moderate activity who did not justify steriod ther-

Table 2 Characteristics, symptoms and physical findings in patients from both groups

\begin{tabular}{lllllllll}
\hline Group & No & $\begin{array}{l}\text { Age } \\
(y r)\end{array}$ & $\begin{array}{l}\text { Sex } \\
(M / F)\end{array}$ & .Nausea & $\begin{array}{l}\text { Abdominal } \\
\text { pain }\end{array}$ & Hepatomegaly & Splenomegaly Ascites \\
\hline Cyanidanol & 16 & $59 \cdot 8 \pm 9$ & $4 / 12$ & 3 & 3 & 11 & 8 & 1 \\
Placebo & 14 & $55 \cdot 3 \pm 10 \cdot 4$ & $6 / 8$ & 3 & 4 & 9 & 4 & 0 \\
\hline
\end{tabular}


Table 3 Initial laboratory tests in both groups

\begin{tabular}{|c|c|c|c|c|c|}
\hline Normal values: & $\begin{array}{l}A S T \\
u / l \\
10-40\end{array}$ & $\begin{array}{l}A L T \\
u / l \\
3-26\end{array}$ & $\begin{array}{l}\text { Alkaline } \\
\text { phosphatase } \\
\text { u/l } \\
0-85\end{array}$ & $\begin{array}{l}\text { Albumin } \\
g \% \\
3 \cdot 8-5 \cdot 4\end{array}$ & $\begin{array}{l}\text { Globulin } \\
2 \cdot 0-3 \cdot 0\end{array}$ \\
\hline $\begin{array}{l}\text { Cyanidanol } \\
\text { Placebo }\end{array}$ & $\begin{array}{c}88 \pm 54 \\
116 \pm 66^{*}\end{array}$ & $\begin{array}{l}75 \pm 44 \\
78 \pm 42\end{array}$ & $\begin{array}{l}103 \pm 48 \\
133 \pm 54\end{array}$ & $\begin{array}{l}4 \cdot 0 \pm 0 \cdot 3 \\
3 \cdot 9 \pm 0 \cdot 3\end{array}$ & $\begin{array}{l}3.6 \pm 0.4 \\
3.4 \pm 0.4\end{array}$ \\
\hline
\end{tabular}

${ }^{*} \mathrm{p}<0.05$

Table 4 Initial liver histology in both groups

\begin{tabular}{|c|c|c|c|c|c|c|c|}
\hline Group & Severity & $\begin{array}{l}\text { Piecemeal } \\
\text { necrosis }\end{array}$ & $\begin{array}{l}\text { Intralobular } \\
\text { necrosis }\end{array}$ & Steatosis & $\begin{array}{l}\text { Portal } \\
\text { fibrosis }\end{array}$ & $\begin{array}{l}\text { Intralobular } \\
\text { fibrosis }\end{array}$ & $\begin{array}{l}\text { Portal } \\
\text { inflammation }\end{array}$ \\
\hline \multirow{4}{*}{ Cyanidanal } & None & 0 & 6 & 7 & 0 & 0 & 0 \\
\hline & Mild & 5 & 2 & 6 & 5 & 5 & 5 \\
\hline & Moderate & 6 & 4 & 2 & 10 & 3 & 9 \\
\hline & Severe & 5 & 4 & 1 & 1 & 8 & 2 \\
\hline \multirow{4}{*}{ Placebo } & None & 0 & 3 & 4 & 0 & 0 & 0 \\
\hline & Mild & 3 & 5 & 5 & 3 & 2 & 3 \\
\hline & Moderate & 5 & 3 & 4 & 4 & 3 & 5 \\
\hline & Severe & 6 & 3 & 1 & 7 & 9 & 6 \\
\hline
\end{tabular}

Table 5 Symptoms and physical findings in both groups at the beginning and at the end of the study

\begin{tabular}{lllllll}
\hline Group & Stage & Nausea & $\begin{array}{l}\text { Abdominal } \\
\text { pain }\end{array}$ & Hepatomegaly & Splenomegaly & Ascites \\
\hline Cyanidanol & Beginning & 3 & 3 & 11 & 8 & 1 \\
& End & 1 & 2 & 9 & 7 & 0 \\
\hline Placebo & Beginning & 3 & 4 & 9 & 4 & 0 \\
& End & 2 & 2 & 4 & 0 \\
\hline
\end{tabular}

Table 6 Number of patients with 50\% variation in laboratory tests at end of the study

\begin{tabular}{|c|c|c|c|c|c|c|}
\hline Group & Response & $A S T$ & $A L T$ & Alkaline phos. & Albumin & Globulin \\
\hline Cyanidanol & $\begin{array}{l}\text { No change } \\
\text { Better } \\
\text { Worse }\end{array}$ & $\begin{array}{r}12 \\
2 \\
2\end{array}$ & $\begin{array}{r}12 \\
0 \\
4\end{array}$ & $\begin{array}{r}15 \\
0 \\
1\end{array}$ & $\begin{array}{r}16 \\
0 \\
0\end{array}$ & $\begin{array}{r}16 \\
0 \\
0\end{array}$ \\
\hline Placebo & $\begin{array}{l}\text { No change } \\
\text { Better } \\
\text { Worse }\end{array}$ & $\begin{array}{l}9 \\
3 \\
2\end{array}$ & $\begin{array}{r}10 \\
2 \\
2\end{array}$ & $\begin{array}{r}14 \\
0 \\
0\end{array}$ & $\begin{array}{r}13 \\
1 \\
0\end{array}$ & $\begin{array}{r}13 \\
0 \\
1\end{array}$ \\
\hline
\end{tabular}

Better - Decrease by more than $50 \%$ from initial value

Worse - Increase by more than $50 \%$ from initial value 
Table 7 The effect of therapy on the kistological findings

\begin{tabular}{llll}
\hline Drug & No change & Better & Worse \\
\hline Cyanidanol & 2 & 1 & 10 \\
Placebo & 1 & 6 & 4 \\
\hline
\end{tabular}

apy, were included. For ethical reasons we did not wish to deprive patients from steriod therapy if needed. Therefore, all patients who had either a 10fold rise of serum transaminase or a five-fold rise of serum transaminase and a two-fold rise of serum $\gamma$-globulin were excluded. ${ }^{16}$ This study shows that cyanidanol is not effective in chronic active hepatitis patients with mild or moderate activity.

There were two previous studies where cyanidanol was given to patients with chronic active hepatitis. In the first study, two groups of patients with chronic active hepatitis were studied ${ }^{15}$ After a six week run in period during which all patients received prednisolone alone at a dose of $15 \mathrm{mg} /$ day, a placebo was added to prednisolone in the control group and cyanidanol $1.5 \mathrm{~g} / \mathrm{d}$ in the other group, for a period of six months, on a double blind randomised basis. No significant differences between the two groups were noted with respect to the clinical and biological evaluation. In contrast, there was a significant improvement of the histological picture of the liver in the group receiving cyanidanol. The favourable response was even more pronounced in HBsAg-negative patients.

In the second study two groups of patients with biopsy proven chronic active hepatitis were studied for six months. ${ }^{14}$ Patients in the control group received placebo and patients in the other group received cyanidanol, $3 \mathrm{~g} / \mathrm{d}$. There were no significant differences in the evaluation of symptoms, laboratory tests, and histological findings in the two groups.

The design of our study and the results are similar to the second study carried out by Piazza et al, except that all our cyanidanol treated patients were HBsAg negative. In the other study half of the patients were $\mathrm{HBsAg}$ positive, but none became negative in the course of the study. The HBsAg negative group did not behave differently from the HBsAg positive group. As in both studies no effect of cyanidanol was seen, it is surprising that its addition to prednisone improved the histological picture. It may be because of either sampling error on the liver biopsy or synergism between prednisone and cyanidanol.

Another trial is recommended when both corticosteroids and cyanidanol are administered, particularly in HBsAg positive chronic active hepatitis patients, where steroid therapy is less effective.

\section{References}

1 Gajdos A, Gajdos-Török M, Horn R. The effect of $(+)$-catechin on the hepatic level of ATP and the lipid content of liver during experimental steatosis. Biochem Pharmacol 1971; 21: 595-600.

2 Reutter W, Hassels B, Lesch R. Induction and prevention of galactosamine hepatitis. In: Bertelli A, ed. New trends in the therapy of liver diseases. Basel: Karger, 1975: 121-7.

3 Slater TF, Eakins MN. Interaction of (+)-cyanidanol-3 with free radical generation systems. In: Bertelli A, ed. New trends in liver diseases. Basel: Karger, 1975: 84-90.

4 Slater TF, Scott R. Free radical scavenging action of $(+)$-cyanidanol-3 in relation to the toxicity of carbon tetrachloride. In: Conn HO, ed. (+)-cyanidanol-3 in diseases of the liver. International Workshop. London: Academic Press and The Royal Society of Medicine, 1981: 33-9.

5 Kappus H. (+)-cyanidanol-3 inhibition of lipid peroxidation induced by hepatotoxic chemicals in the rat. In: Conn HO, ed. (+)-cyanidanol-3 in diseases of the liver. International Workshop. London: Academic Press and The Royal Societyof Medicine, 1981: 17-20.

6 Siegens CP. Antihepatotoxic activity of (+)cyanidanol-3 in acute and chronic experimental liver injury. In: Conn HO, Ed. (+)-cyanidanol-3 in diseases of the liver. International Workshop. London: Academic Press and The Royal Society of Medicine, 1981: 19-20.

7 Blum AL, Doelle W, Kortüm K, et al. Treatment of acute viral hepatitis with $(+)$-cyanidanol-3. Lancet 1977; 2: 1153-5.

8 Seyfried H, Brunner H, Grabner G. (+)-cyanidanol-3 treatment in acute viral hepatitis. In: Bertelli A, ed. New trends in the therapy of liver diseases. Basel: Karger, 1975: 177-81.

9 Berengo A, Esposito R. A double-blind trial of (+)-cyanidanol-3 in viral hepatitis In: Bertelli A, ed. New trends in the therapy of liver diseases. Basel: Karger, 1975: 182-90.

10 Kafkias B, Papachristou A, Hatzidimou M, et al. The treatment of hepatitis $B$ and other liver diseases with (+)-cyanidanol-3 In: Conn HO, ed. (+)-cyanidanol-3 in diseases of the liver. International Workshop. London: Academic Press and The Royal Society of Medicine, 1981, 93-5.

11 Piazza M, Guadagnini V, Piciotto L, et al. Effect of (+)-cyanidanol-3 in acute $A, B$, and non- $A$, non-B viral hepatitis. Hepatology 1982; 3: 45-9.

12 Theodoropoulos G, Dinos A, Dimitriou P, et al. Effect of $(+)$-cyanidanol-3 in acute viral hepatitis. In: Conn $\mathrm{HO}$, ed. (+)-cyanidanol-3 in diseases of the liver. International Workshop. London: Academic Press and The Royal Society of Medicine, 1981: 89-91.

13 Schomerus H, Wiedmann KH, Dölle W. (+)cyanidanol-3 in the treatment of hepatitis: a randomized controlled trial. Hepatology 1984; 4: 331-5.

14 Piazza M, De Mercato R, Guadagnino V. Effect of $(+)$-cyanidanol-3 on chronic persistent and chronic active hepatitis. In: Conn HO, ed. (+)-cyanidanol-3 in 
diseases of the liver. International Workshop. London: Academic Press and The Royal Society of Medicine, 1981: 123-9.

15 Demeulenare F, Desmet VJ, Dupont E, et al. Study of (+)-cyanidanol-3 in chronic active hepatitis. Results of a controlled multicentre study. In: Conn HO, ed. (+)-cyanidanol-3 in diseases of the liver. International
Workshop. London: Academic Press and The Royal Society of Medicine, 1981: 135-41.

16 Soloway RD, Summerskill WHJ, Baggenstoss AH, et al. Clinical, biochemical, and histological remission of severe chronic active disease: a controlled study of treatment and early prognosis. Gastroenterology 1972; 63: $820-33$. 